\title{
Preoperative Role of Dynamic Abdominal Computed Tomography in Gastric Tumors
}

\section{Gastrik Tümörlerde Dinamik Abdominal Bilgisayarlı Tomografinin Preoperatif Rolü}

\author{
$\underline{\text { Mehmet Saydam }}^{1}$, Serra Ozbal Gunes ${ }^{2}$, Ibrahim Yilmaz ${ }^{1}$, Mehmet Alperen Avci ${ }^{1}$, Mutlu Sahin ${ }^{3}$, Mustafa Taner \\ Bostanci $^{1}$ \\ ${ }^{1}$ Dışkapı Yıldııım Beyazıt Eğitim ve Araştırma Hastanesi Genel Cerrahi Servisi, Ankara \\ ${ }^{2}$ Dışkapı Yıldırım Beyazıt Eğitim ve Araştırma Hastanesi Radyoloji Servisi, Ankara \\ ${ }^{3}$ Keçiören Eğitim ve Araştırma Hastanesi, Genel Cerrahi Servisi, Ankara
}

Dergiye Ulaşma Tarihi: 07.07.2019 Dergiye Kabul Tarihi:07.10.2019 Doi: 10.5505/aot.2020.02693

\section{ÖZET}

GİRIŞ ve AMAÇ: Mide kanseri tüm dünyada her y1l yaklaşık yarım milyon hastanın ölümüne neden olmaktadır. Dinamik abdominal BT preoperatif tanı ve mide kanserlerinin evrelemesinde yaygın olarak kullanılmaktadır. Burada en önemli nokta preoperatif evrelemenin doğru yapılarak, hastaların neoadjuvan kemoterapi gibi uygun tedavi seçeneklerine kavuşabilmesidir. Dinamik abdominal BT'nin preoperatif rolünü daha da netleştirmek için; preoperatif BT bulgularını postoperatif ve histopatolojik bulgular eşliğinde karșlaștırdık.

YÖNTEM ve GEREÇLER: Mide kanseri nedeniyle 2016 - 2019 yılları arasında operasyon geçiren hastaların kayıtları geriye dönük olarak incelendi. Tüm preoperatif BT bulguları cerrahi bulgularla istatistiksel olarak karşılaştırıldı ve preoperatif BT görüntüleri ameliyat sonrası başka bir radyolog tarafından değerlendirildi. BULGULAR: Üç yıl boyunca kliniğimizde toplam 103 hastaya mide kanseri tanısı konuldu ve opere edildi. İncelenen hastaların 76 'sı (\% 73.7) erkek ve 25 ' i (\% 24.2) kadındı ve ortalama yaş 67' idi.Tüm hastalara preoperatif dinamik abdominal BT inceleme yapıldı. Preoperatif BT bulguları evreleme ve tanı için ayrıca hastanın 16' sında (\% 15.84) yetersizdi. Bu 16 hastanın ek görüntüleme teknikleri (PET CT, MR, EUS) ve endoskopi nedeniyle tedavi seçenekleriyle, mortalite ve morbidite oranları değişmedi. TARTIŞMA ve SONUÇ: Dinamik abdominal BT' nin mide tümörlerinde preoperatif tanı ve evrelemesinde önemli bir rolü vardır, ancak bazı vakalar yanlış değerlendirilebildiği veya gözden kaçabildiği görülmektedir. $\mathrm{Bu}$ yüzden mide tümörü düşünülen hastalarda preoperatif evreleme yapılırken BT yanında primer olarak endoskopi ve sonrasında MRI, PET, EUS gibi ek görüntüleme yöntemleriyle değerlendirilmesi önemli olarak görülmektedir.

Anahtar Kelimeler: Dinamik Abdominal Batın BT, Preoperative Evreleme, Mide Tümörleri

\begin{abstract}
INTRODUCTION: Gastric cancer accounts for nearly half a million deaths each year all over the world. Dynamic abdominal CT is used for preoperative diagnosis and staging of gastric cancers. Preoperative staging must be done correctly, so the patient can get the proper treatment options such as neoadjuvan chemotherapy. To further clarify of preoperative role of dynamic abdominal CT; we compared preoperative CT findings with postoperative, and histopathological findings.

METHODS: Patients' records, who underwent gastric operation for gastric cancer, between 2016 to 2019 were analyzed retrospectively. All preoperative CT findings were compared with surgical and histopathological findings statistically, and also preoperative CT images were evaluated by another radiologist postoperatively.

RESULTS: For 3 year period total 103 patients were diagnosed and operated for gastric cancer in our clinic. The population was comprised of $76(73.7 \%)$ male and 25(24.2\%) female patients who were averagely 67 years old. All of the patients have preoperative dynamic abdominal CT. Preoperative CT findings for staging and also diagnosis were insufficient for $16(15.84 \%)$ patients of 101 . The treatment options, mortality and morbidity rates for 16 patients did not change, because additional imaging technics (PET CT, MRI, EUS) and endoscopy were performed to these patients preoperatively.
\end{abstract}


DISCUSSION AND CONCLUSION: Dynamic abdominal CT has a major role for preoperative diagnosis and staging of gastric tumors, but some cases could be misevaluated, so that preoperative evaluation of gastric tumors should be done with dynamic CT and if necessary MRI, PET CT, EUS or endoscopy.

Keywords: Abdominal CT, Gastric Tumors, Preoperative Staging

\section{INTRODUCTION}

Gastric cancers are the fourth most seen cancer and the second leading cause of cancer-related mortality worldwide and also the most prevalent cancer in Eastern Asia (1).Incidence rates are 2-3 times higher for male population (2). Age, male sex, smoking, black or Hispanic race, Helicobacter pylori, low socioeconomic status, smoked food, non- steroidal antiinflammatory drugs, statins, obesity, gastroesophagial reflux disease are risk factors of gastric cancer (3). Nowadays, although the incidence of the gastric cancer varies regionally, proximal migration has begun to be seen more frequently, so it leads to the introduction of the FLOT (5FU, Folinic acid, Oxaliplatin, Docetaxel) regimen into the treatment protocols and also the NCCN 2018 guideline changed and the regimen in question has become the main treatment especially in upper gastrointestinal tumors (4).

Upper gastrointestinal endoscopy is the gold standard for the diagnosis of gastric tumors (5). Most of the gastric cancers are adenocarsinomas originating from stomach's superficial layer or mucosa (3).Dynamic Computed Tomography (CT) is used preoperativelyfor both diagnosis and staging of gastric cancer. Proper treatment whether neoadjuvan chemotherapy or surgical optionsisperformed according to the CT. While evaluation of CT images could be difficult, because of some technical details such asbeing gastric wall thickness as 7-10 $\mathrm{mm}$ and distended stomach recommended during the procedure (6).Preoperative staging with $\mathrm{CT}$ could result in understaging or overstaging of the gastric cancer patients. Adjacent organ invasion, normal sized metastatic lymph nodes or enlarged lymph nodes without metastasis may effect in staging status (6). Dynamic CT is essential for $\mathrm{T}$ staging for precise localization of the gastric lesions(7).Preoperative evaluation and staging for gastric cancer is essential foridentifying the treatment options. Our goal is to determine the preoperative efficiency of dynamic abdominal CT for gastric cancers.

\section{METHODS}

A total of 103 patients underwent gastric operation for gastric cancer between 2016 to 2019 at the Department of General Surgery in Dişkapi Yildirim Beyazit University Training and Research Hospital were included in this retrospective study and all data were obtained from hospital records. Approval for the study was granted by the Ethics Committee of Dişkapi Yildirim Beyazit University Training and Research Hospital. Preoperative abdominal CT findings, intraoperative findings, postoperative histopathological findings and postoperative re-examination of CT findings were recorded and analyzed statistically.

\section{RESULTS}

Demographics of the patients were; 76 (73.7\%) male and 25(24.2\%) female patients who were averagely 67 (38-88 range) years old. All of the patients had preoperative CT and abdominal USG, and findings analysed for staging and diagnosis. Preoperative 11(10.6\%) abdominal CT didn't report any pathologic findings, whereby the patients had gastric tumors. Preoperative CT could not identify metastatic lymph nodes for 2(1.9\%) patients. For 3 patients CT could not localize the mass precisely. One was gastric cardia mass; reported as prepyloric, one was gastric and colon tumor with liver metastasis; reported as only colon tumor with liver metastasis and one gastric tumor; reported as intrabdominal mass. 
The characteristics of 16 patients listed in Table 1.

We performed subtotal or total gastrectomy with Roux-n-Y anastomosis with D2 lymph node dissection for gastric tumors due to localization of the tumor. All patients specimens were reported histopathologically as adenocarsinoma of stomach. These CT findings discussed with a radiologist postoperatively, and confirmed.

\section{DISCUSSION}

Gastric cancer is one of the leading causes of cancer deaths worldwide. Expected5-year survival is approximately $25 \%$ and most cases are advanced stage when diagnosed and whose surgical treatment options are limited (8). Adenocarcinomasforms $95 \%$ of all gastric carcinomas. Curative treatment of gastric adenocarcinomasis the resection of partial or total stomach (R0) with lymph node dissection (D2) (9). Histological type and lymph node metastasis are the most important prognostic factors for gastric cancer. Gold standard diagnosis of gastric cancer is preoperative upper GIS endoscopy with biopsy (10).Currently, new treatment modalities like perieoperative chemotherapy have gained importance for gastric cancer treatment, but 5year survival rates have remained $35-45 \%$ (11).

To decide on proper treatment modality for gastric cancer depends on preoperative true staging of gastric tumor. CT, positron emission tomography (PET) and endoscopic ultrasonography(EUS) are the most used preoperative staging imaging procedures for gastric cancer (12). Our preoperative and postoperative CT findings about gastric cancer diagnosis and preoperative staging and for some cases EUS, PET or endoscopy were correlated with the literature.CT is frequently preferred for preoperative staging of gastric cancer, and also postoperative patient followup of recurrence and response to treatment therapy (13). CT could define; the mass, tumor depth, size of the mass(T), metastasis(M), lymph nodes $(\mathrm{N})$ and ascites which have been used for TNM staging.CT has controversies such as; detecting local tumor invasion, normal sized metastatic lymph nodes and peritoneal dissemination. Also it exposes patients to ionizing radiation and has poor soft-tissue contrast (14).

The other technical detail was thickness of gastric wall at CT was reported 7$10 \mathrm{~mm}$. If stomach was not distended with oral contrast or any liquid, wrinkled stomach wall could be interpreted as wall thickening, causing false positive finding (6).All patients in our study underwent dynamic CT with intravenous and oral contrast. Enlarged nonmetastatic intraabdominal lymph nodes could also cause overstaging (6).Minami et alreported the accuracy of abdominal CT in diagnosis of 71 early and advanced gastric cancer patients as 53\% and 92\% respectively(15). We had preoperative CT findings insufficient for $16(15,5 \%)$ patients. We concluded that our misevaluted CT findings were mostly emergency cases and were reported urgently and also these results correlated with the literature.

On the other hand CT had similar results for preoperative gastric cancer $\mathrm{T}$ staging with EUS. The accuracy of CT for Tstaging was reported as $77.1-88.9 \%$ and tumor serosalinvolmentspecifity and sensivity rates were reported $82.8-100 \%$ and $80-96.8 \%$ respectively(16).

Kwee et al. reported that CT sensivity for detecting lymp node metastasis was 62.5$91.9 \%$ and specifity as50.0-87.9\% in a systematic review(17). The authors concluded that, normal sized metastatic lymph nodes could be misevulated as normal lymph nodes and reactive enlarged nodes could be commented as metastatic lymph nodes. We detected metastatic lymp nodes histopathologicallyfor 2 patients (1, 94\%) whom preoperative CT findings were reported as non-metastatic lymph nodes. Liu $\mathrm{Y}$ et al. reported that PET/MRI performs better in TN 
staging compared with PET/CT and it should be the optimal imaging technique for an accurate $\mathrm{N}$ staging for gastric cancer(18).

Another challenging issue is the detecting involvement of adjacent organ for gastric cancer with CT. Some authors recommended that absence of fatty plane between mass and organ could be considered as adjacent organ involvement, but for cachectic patients this CT finding could be misleading (19). CT was reported as the modality of choice imaging technique for metastasis during preoperative staging of gastric cancers. Pelvis, abdomen and thorax could be identified for distant metastasis at the same time.Sensivity and specifity of CT detecting gastric cancer distant metastasis reported as $14.3-59.1 \%$ and $93.3-99.8 \%$ respectively (20). Peritoneal metastasis could be difficult to detect with $\mathrm{CT}$ and reported sensitivity was $28.3 \%$ and specifity was 93.3 $99.8 \%(21)$.

Despite the improvements in imaging technics, preoperative staging and treatment modalities of gastric cancer, there has not been a concensus of preoperative imaging of gastric cancer patients worldwide. In the other hand, as perioperative methodology in order toprovide downstage in the tumor stage, increase the chance of $\mathrm{R} 0$ resection, treat micrometastatic disease and improve overall survival have become so crucial. So therole of
CT for preoperative staging in gastric malignancies have been increasing more than ever.

Diagnosis and treatment of gastric cancer should be multidisciplinary team approach to prevent misevaluations and to choose the proper treatment modality for the patient. General surgeons or assistants often interpret the $\mathrm{CT}$ imagings as radiologists do mostly in emergency patients and less in elective cases. Therefore, it is important to note that imaging examinations to be interpreted by experienced gastrointestinal system radiologists may protect patients from unnecessary surgery morbidity or risk of skipping diagnosis because the region in question is quite confusing for interpreting and that false negative cases may been countered due to some technical details.

\section{CONCLUSION}

Gastric cancer management requires a multidisciplinary team approach and still abdominal CT is the first choice of imaging modality due to its relatively high accuracy rates and wide availability.If needed other imaging modalities (EUS, MRI, PET) should be added preoperative period to prevent misevaluation of gastric cancer patients.

Conflict of interest: All of the authors declare that they have no conflict of interest. 
Table 1: Comparison of Preoperative CT Findings with Postoperative Operation and Histopathological Findings

\begin{tabular}{|c|c|c|c|c|c|c|c|}
\hline NO & AGE & GENDER & $\begin{array}{l}\text { PREOPERATIVE ABDOMINAL CT } \\
\end{array}$ & $\begin{array}{l}\text { PREOPERATIVE } \\
\text { ENDOSCOPY }\end{array}$ & $\begin{array}{l}\text { PREOPERATIVEHIST } \\
\text { OPATHOLOGY }\end{array}$ & TYPE OF OPERATION PERFORMED & POSTOPERATIVE HISTOPATHOLOGY \\
\hline 1 & 64 & M & $\begin{array}{c}\text { Gastric antrum wall thickening } \\
\text { without any metastatic lymph } \\
\text { nodes. }\end{array}$ & $\begin{array}{l}\text { Gastric antral ulcer and } \\
\text { mass. }\end{array}$ & Adenocarsinoma & $\begin{array}{c}\text { Distal Subtotal Gastrectomy+ Roux-N-Y } \\
\text { Gastrojejunostomy }\end{array}$ & $\begin{array}{c}\text { Mucinous adenocarsinoma, } 7 / 27 \text { lymph node } \\
\text { mestastasis }\end{array}$ \\
\hline 2 & 40 & $\mathrm{~F}$ & Normal abdominal CT findings & $\begin{array}{l}\text { Gastric mass at antrum- } \\
\text { corpus junction }\end{array}$ & $\begin{array}{l}\text { Malign epithelial } \\
\text { tumor }\end{array}$ & $\begin{array}{l}\text { Total Gastrectomy+ Roux-N-Y } \\
\text { Gastrojejunostomy }\end{array}$ & $\begin{array}{l}\text { Poorly cohesive carcinoma } 1 / 13 \text { lymph node } \\
\text { metastasis }\end{array}$ \\
\hline 3 & 60 & M & $\begin{array}{l}\text { Gastric wall thickening and right } \\
\text { renal mass. }\end{array}$ & Urgent Surgery & $\begin{array}{l}\text { Signet-ring cell } \\
\text { adenocarsinoma }\end{array}$ & $\begin{array}{c}\text { Total Gastrectomy+ Roux-N-Y } \\
\text { Gastrojejunostomy } \\
\text { +Renal mass excision }\end{array}$ & $\begin{array}{l}\text { Gastric adenocarsinoma + Renal papillary } \\
\text { carcinoma, } 32 / 32 \text { gastric lymph node metastasis }\end{array}$ \\
\hline 4 & 79 & M & Pyloric circular wall thickening & Gastric mass at cardia & Adenocarsinoma & $\begin{array}{l}\text { Total Gastrectomy+ Roux-N-Y } \\
\text { Gastrojejunostomy }\end{array}$ & Adenocarsinoma, no lymphnode metastasis \\
\hline 5 & 59 & M & Normal abdominal CT findings & Gastric mass atcorpus & Adenocarsinoma & $\begin{array}{l}\text { Total Gastrectomy+ Roux-N-Y } \\
\text { Gastrojejunostomy }\end{array}$ & Adenocarsinoma $1 / 51$ lymphnode metastasis \\
\hline 6 & 45 & M & Normal abdominal CT findings & Gastric mass in antrum & $\begin{array}{l}\text { Malign epithelial } \\
\text { tumor }\end{array}$ & $\begin{array}{l}\text { Total Gastrectomy+ Roux-N-Y } \\
\text { Gastrojejunostomy }\end{array}$ & $\begin{array}{l}\text { Adenocarsinoma "poorly cohesive", } 0 / 20 \text { lymph } \\
\text { node metastasis }\end{array}$ \\
\hline 7 & 70 & m & $\begin{array}{l}\text { Sigmoid colon wall thickening with } \\
\text { liver masses }\end{array}$ & Urgent Surgery & Adenocarsinoma & $\begin{array}{c}\text { Total Gastrectomy+ Roux-N-Y } \\
\text { Gastrojejunostomy + Total coloctomy }\end{array}$ & Adenocarsinoma of stomach and colon \\
\hline 8 & 47 & $\mathrm{M}$ & Normal abdominal CT findings & $\begin{array}{l}\text { Gastric mass in } \\
\text { prepyloric area }\end{array}$ & Adenocarsinoma & $\begin{array}{l}\text { Total Gastrectomy+ Roux-N-Y } \\
\text { Gastrojejunostomy }\end{array}$ & Adenocarsinoma, $0 / 35$ lymph node mestastasis \\
\hline 9 & 83 & M & Normal abdominal CT findings & Gastric mass at corpus & $\begin{array}{l}\text { Signet-ring cell } \\
\text { adenocarsinoma }\end{array}$ & Laparotomy, Peritonitis Carsinomatosa & Adenocarsinoma in frozen section \\
\hline 10 & 88 & $F$ & $\begin{array}{l}3 \mathrm{~cm} \text { sized, right abdominal located } \\
\text { mass near small intestine }\end{array}$ & Urgent Surgery & Adenocarsinoma & $\begin{array}{l}\text { Total Gastrectomy+ Roux-N-Y } \\
\text { Gastrojejunostomy }\end{array}$ & Adenocarsinoma, $2 / 26$ lymph node mestastasis \\
\hline 12 & 46 & $F$ & Normal abdominal CT findings & $\begin{array}{c}\text { Gastric mass in angular } \\
\text { area }\end{array}$ & Adenocarsinoma & Distal Subtotal Gastrectomy+ Billroth 2 & $\begin{array}{l}\text { Early gastric adenocarsinoma without lymph } \\
\text { node metastasis }\end{array}$ \\
\hline 13 & 69 & M & Normal abdominal CT findings & Gastric mass at cardia & Adenocarsinoma & $\begin{array}{l}\text { Total Gastrectomy+ Roux-N-Y } \\
\text { Gastrojejunostomy }\end{array}$ & Adenocarsinoma, $0 / 28$ lymph node mestastasis \\
\hline 14 & 82 & m & Normal abdominal CT findings & Gastric mass at cardia & Adenocarsinoma & $\begin{array}{l}\text { Total Gastrectomy+ Roux-N-Y } \\
\text { Gastrojejunostomy }\end{array}$ & Adenocarsinoma, $11 / 20$ lymph node mestastasis \\
\hline 15 & 74 & M & Normal abdominal CT findings & $\begin{array}{l}\text { Gastric mass in } \\
\text { prepyloric area }\end{array}$ & Adenocarsinoma & $\begin{array}{l}\text { Total Gastrectomy+ Roux-N-Y } \\
\text { Gastrojejunostomy+Splenectomy }\end{array}$ & Adenocarsinoma, $0 / 18$ lymph node mestastasis \\
\hline 16 & 72 & M & Normal abdominal CT findings & $\begin{array}{l}\text { Gastric mass in } \\
\text { prepyloric area }\end{array}$ & Adenocarsinoma & $\begin{array}{l}\text { Total Gastrectomy+ Roux-N-Y } \\
\text { Gastrojejunostomy+Splenectomy }\end{array}$ & Adenocarsinoma, $6 / 24$ lymph node mestastasis \\
\hline
\end{tabular}




\section{REFERENCES}

1. Bray F, Ren JS, Masuyer E, Ferlay J. Global estimates of cancer prevalence for 27 sites in the adult population in 2008. Int $\mathbf{J}$ Cancer. 2013; 132:1133-45.

2. Ferlay J, Shin HR, Bray F, Forman D, Mathers C, Parkin DM. Estimates of worldwide burden of cancer in 2008: GLOBOCAN 2008. Int J Cancer. 2010; 127:2893-917

3. Karimi P, Islami F, Anandasabapathy S, Freedman ND, Kamangar F. Gastric Cancer: Descriptive Epidemiology, Risk Factors, Screening, and PreventionCancer Epidemiol Biomarkers Prev. 2014; 23(5): 700-713.

4. Al-Batran Salah-Eddin, PauligkClaudia, HomannNils, Schmalenberg Harald, Kopp HansGeorg, Haag Georg Martin, et al. Docetaxel, oxaliplatin, andfluorouracil/leucovorin (FLOT) versusepirubicin, cisplatin, and fluorouracilor capecitabine $(\mathrm{ECF} / \mathrm{ECX})$ as perioperative treatment of resectable gastric or gastroesophageal junction adeno carcinoma: The multi center, randomized phase 3 FLOT4 trial (GermanGastricGroup at AIO). Ann. Oncol. 2017 Jun 1;28 (suppl-3): doi:10.1093/annonc/mdx302

5. Areia M, Carvalho R, Cadime AT, Rocha Goncalves F, Dinis-Ribeiro M. Screening for gastric cancer and surveillance of premalignant lesions: a systematic review of cost-effectiveness studies. Helicobacter.2013; 18:325-37.

6. Fishman EK, Urban BA, Hruban RH. CT of the Stomach.Raiographics.1996 Sep.; 16(5):1035-20.

7. Kim W, Shin SS, Heo SH, Lim HS, Lim NY, Park YK, Jeong YY, KangHK.The Role of ThreeDimensional Multidetector CT Gastrography in the Preoperative Imaging of Stomach Cancer: Emphasis on Detection and Localization of the Tumor. Korean J Radiol 16(1), Jan/Feb 2015.

8. Rawicz-Pruszyński K, Sandick JW, Mielko J, Cise $\mathrm{B}$, Polkowski WP, Current challenges in gastric cancer surgery:European perspective., Surgical Oncology (2018). 10.1016/j.suronc.2018.08.004.

9. Japanese Gastric Cancer Association. Japanese gastric cancer treatment guidelines 2014(ver. 4). Gastric Cancer. 2017;20(1):1-19. doi:10.1007/s10120-016-0622-4.

10. Liu S, Liu Song, Ji C, et al. Application of CT texture analysis in predicting histopathological characteristics of gastric cancers. EurRadiol. 2017;27:4951-9.

11. Al-BatranS-E, Homann N, Pauligk C, et al. Effect of Neoadjuvant Chemotherapy Followed by Surgical Resection on Survival in Patients With Limited Metastatic Gastric or Gastroesophageal
Junction Cancer. JAMA Oncol. 2017;3(9):1237.doi:10.1001/jamaoncol.2017.0515.

12. Seevaratnam R, Cardoso R, Mcgregor C, et al. How useful is preoperative imaging for tumor,node, metastasis (TNM) staging of gastric cancer? A meta-analysis.Gastric Cancer. 2012;15(S1):3-18. doi:10.1007/s10120-011-0069-6.

13. Park CJ, Seo N, Hyung WJ, KoomWS,Kim HS, Kim M-J, et al. (2018) Prognosticsignificance of preoperative CT findings in patientswith advanced gastric cancer who underwentcurative gastrectomy. PLoS ONE 13(8): e0202207.

14. Borggreve AS, Goense L, Brenkman HJF, Mook S, Meijer GJ, Wessels FJ, VerheijM,JansenEPM,Hillegersberg R, Rossum PSN, Ruurda JP. Imaging strategies in the management of gastric cancer: current role and future potential of MRI.British Institute of Radiology. doi.org/10.1259/bjr.20181044.

15. Minami M, Kawauchi N, Itai Y, Niki T, Sasaki Y. Gastric tumors: radiologic-pathobogic correlation and accuracy of CT staging with dynamic CT. Radiology 1992; 185:173-178.

16. Kwee RM, Kwee TC. Imaging in Local Staging of Gastric Cancer: A Systematic Review. J ClinOncol. 2007;25(15):2107-2116. doi:10.1200/JCO.2006.09.5224.

17. Kwee RM, Kwee TC. Imaging in assessing lymph node status in gastric cancer.GastricCancer. 2009;12(1):6-22. doi:10.1007/s10120-008-0492-5.

18. Liu, Y., Zheng, D., Liu, J. J., Cui, J. X., Xi, H. Q., Zhang, K. C., Huang, X. H., Wei, B., Wang, X. X., Xu, B. X., Li, K., Gao, Y. H., Liang, W. Q., Tian, J. H. Chen, L. (2019). Comparing PET/MRI with PET/CT for Pretreatment Staging of Gastric Cancer. Gastroenterology research and practice, 2019, 9564627. doi:10.1155/2019/9564627.

19. Cook A, Levine BA, Sirinek KR, et al. Evaluation of gastric adenocarcinoma. Arch Surg 1986;121:603-6.

20. Kwee RM, Kwee TC. Modern imaging techniques for preoperative detection of distant metastases in gastric cancer.World J Gastroenterol. 2015;21(37):10502-10509.

21. Kim SJ, Kim H-H, Kim YH, et al. Peritoneal metastasis: detection with 16- or 64-detector row CT in patients undergoing surgery for gastric cancer. Radiology. 2009;253(2):407-415. 